\title{
Spectroscopic Investigations, DFT Calculations, and Molecular Docking Studies of the Anticonvulsant (2E)-2-[3-(1H-Imidazol-1-yl)-1-phenylpropylidene]- $\mathrm{N}-(4-$ methylphenyl)hydrazinecarboxamide
}

\author{
Reem I. Al-Wabli, ${ }^{1}$ Devarasu Manimaran, ${ }^{2}$ Liji John, ${ }^{2}$ Isaac Hubert Joe, ${ }^{2}$ \\ Nadia G. Haress, ${ }^{1}$ and Mohamed I. Attia ${ }^{1,3}$ \\ ${ }^{1}$ Department of Pharmaceutical Chemistry, College of Pharmacy, King Saud University, P.O. Box 2457, Riyadh 11451, Saudi Arabia \\ ${ }^{2}$ Centre for Molecular and Biophysics Research, Department of Physics, Mar Ivanios College, Thiruvananthapuram, \\ Kerala 695015, India \\ ${ }^{3}$ Medicinal and Pharmaceutical Chemistry Department, Pharmaceutical and Drug Industries Research Division, \\ National Research Centre (ID: 60014618), El Bohooth Street, Dokki, Giza 12622, Egypt
}

Correspondence should be addressed to Isaac Hubert Joe; hubertjoe@gmail.com and Mohamed I. Attia; mattia@ksu.edu.sa

Received 20 February 2016; Accepted 26 April 2016

Academic Editor: Vincenza Crupi

Copyright ( 2016 Reem I. Al-Wabli et al. This is an open access article distributed under the Creative Commons Attribution License, which permits unrestricted use, distribution, and reproduction in any medium, provided the original work is properly cited.

Drug discovery for the management of neurological disorders is a challenging arena in medicinal chemistry. Vibrational spectral studies of (2E)-2-[3-(1H-imidazol-1-yl)-1-phenylpropylidene]-N-(4-methylphenyl)hydrazinecarboxamide ((2E)-IPPMP) have been recorded and analyzed to identify the functional groups and intermolecular/intramolecular interactions of the title molecule. The blue shift of the $\mathrm{C}-\mathrm{H}$ stretching wavenumber reveals the presence of improper $\mathrm{C}-\mathrm{H} \cdots \mathrm{O}$ hydrogen bonding. The equilibrium geometry, harmonic vibrational wavenumbers, Frontier orbital energy, and natural bond orbital analyses have been carried out using density functional theory with a B3LYP/6-311++G(d,p) level of the basis set. The vibrational modes have been unambiguously assigned using potential energy distribution analysis. The scaled wavenumbers are in good agreement with the experimental results. Natural bond orbital analysis has confirmed the intermolecular/intramolecular charge transfer interactions. HOMO-LUMO analysis was carried out to explore charge delocalization on the (2E)-IPPMP molecule. A molecular docking study has supported the anticonvulsant activity of the title molecule.

\section{Introduction}

Epilepsy is a rather neurobiological group of disorders. It has multiple origins and aspects depending upon the affected brain areas. It affects nearly 50 million people of the world's population [1-3]. The hydrazinecarboxamide derivatives have a wide spectrum of biological activities. Among these activities are anticancer and antioxidant [4], antifertility [5], antimicrobial [6,7], anticonvulsant [8,9], and anti-inflammatory [10] activities. The title molecule (2E)-2-[3-(1H-imidazol-1-yl)-1-phenyl-propylidene]- $N$-(4-methylphenyl)hydrazinecarboxamide ((2E)-IPPMP) was synthesized in our laboratory and its crystal structure was previously reported [11]. (2E)-IPPMP exhibited anticonvulsant activity with $83 \%$ and $50 \%$ seizure protection at a dose level of $718 \mu \mathrm{mol} / \mathrm{kg}$ in subcutaneous pentylenetetrazole (scPTZ) and maximal electroshock seizure (MES) screens, respectively, without any neurotoxicity [9].

Literature screening indicated that computational studies on the (2E)-IPPMP molecule have not yet been reported. Therefore, detailed investigations of structural properties and vibrational spectral analysis of the (2E)-IPPMP molecule were carried out in the present study using density functional theory (DFT) computations. Moreover, the biological 


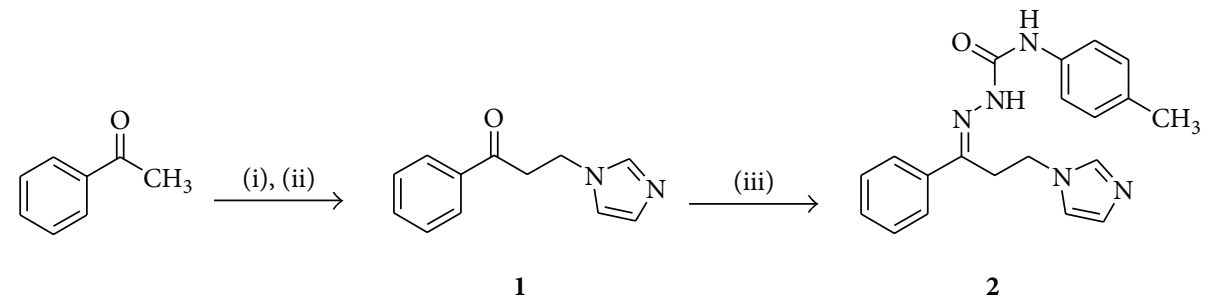

SCHEme 1: Synthesis of the title molecule (2E)-IPPMP. Reagents and conditions: (i) $\mathrm{HN}\left(\mathrm{CH}_{3}\right)_{2} \cdot \mathrm{HCl},\left(\mathrm{CH}_{2} \mathrm{O}\right)_{n}$, conc. $\mathrm{HCl}$, ethanol, reflux, $2 \mathrm{~h}$; (ii) imidazole, water, reflux, $5 \mathrm{~h}$; (iii) $\mathrm{N}$-(4-methylphenyl)hydrazinecarboxamide, few drops of acetic acid, ethanol, RT, $18 \mathrm{~h}$.

activity of the title molecule has been predicted by molecular docking analysis. It is expected that the current investigations might support the development of new potent anticonvulsant agents.

\section{Experimental}

2.1. General. Melting point was recorded on a Gallenkamp melting point instrument and it is uncorrected. The Fourier transform infrared spectrum of MMIMI was recorded on a Perkin Elmer RXL spectrometer (Waltham, Massachusetts, USA) in the region $4000-400 \mathrm{~cm}^{-1}$, with samples in the $\mathrm{KBr}$ pellet method. The resolution of the spectrum was $2 \mathrm{~cm}^{-1}$. The FT-Raman spectrum was measured in the range 3500 $50 \mathrm{~cm}^{-1}$ using a Bruker RFS 100/S FT-Raman spectrophotometer (Ettlingen, Germany) with a $1064 \mathrm{~nm} \mathrm{Nd:YAG} \mathrm{laser}$ source of $100 \mathrm{~mW}$ power (Göttingen, Germany).

2.2. Synthesis. A solution containing $N$-(4-methylphenyl)hydrazinecarboxamide [12] $(1.65 \mathrm{~g}, 10 \mathrm{mmol}), 3$ - $(1 \mathrm{H}$-imidazol1-yl)-1-phenylpropan-1-one (2.00 g, $10 \mathrm{mmol})$ [13], and a few drops of glacial acetic acid in ethanol $(15 \mathrm{~mL})$ was stirred at room temperature for $18 \mathrm{~h}$. The reaction mixture was evaporated under reduced pressure and the residue was crystallized from ethanol to give $1.67 \mathrm{~g}(48 \%)$ of the title compound as colorless crystals (m.p. 476-478 K) which were suitable for single crystal X-ray analysis. ${ }^{1} \mathrm{H}$ and ${ }^{13} \mathrm{C}$ NMR as well as the mass spectral data of the title compound $\mathbf{2}$ are in accordance with the previously reported ones [9].

2.3. Theoretical Calculations. All DFT calculations of the (2E)-IPPMP molecule were performed using the Gaussian 09 program package [14] at the Becke3-Lee-Yang-Parr (B3LYP) level with a $6-311++G(d, p)$ basis set [15-17]. The structural parameters were computed in the gas phase as well as in the liquid phase using a polarizable continuum model (PCM) method. In order to correct the overestimations arising from some negative factors such as basis set truncation effect, neglecting electron correlations, and anharmonicity characters of the vibrational modes, the calculated wavenumbers were scaled using a uniform scaling factor of $0.9673[18,19]$. Theoretical NMR calculation was performed on the basis of the GIAO (gauge-independent atomic orbitals) theory method using a Gaussian program.

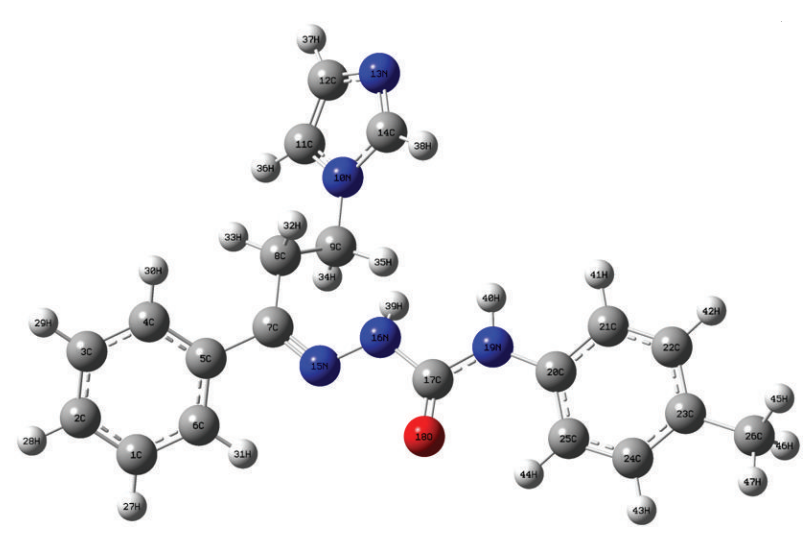

FIGURE 1: Optimized structure of (2E)-IPPMP.

\section{Results and Discussion}

3.1. Synthesis. The target compound (2E)-IPPMP was obtained in a three-step reaction sequence as given in Scheme 1.

3.2. Structural Geometry Analysis. The structure of the (2E)IPPMP molecule was optimized using the B3LYP method with a $6-311++G(d, p)$ basis set. The optimized molecular structure of the isolated molecule is shown in Figure 1. The optimized geometrical parameters of the isolated $(2 E)$ IPPMP molecule in the gas and water phases are given in Table 1 . The calculated values were compared with the $\mathrm{X}$ ray diffraction results. In the (2E)-IPPMP molecule the two phenyl rings are bridged by a hydrazinecarboxamide skeleton containing an imidazole ring. The $\mathrm{C}-\mathrm{N}$ bond lengths $\mathrm{C}_{17}-\mathrm{N}_{16}$ $(1.4179 \AA)$ and $\mathrm{C}_{17}-\mathrm{N}_{19}(1.3792 \AA)$ are shorter than the normal single C-N bond length $1.480 \AA$ [20]. This discrepancy is due to the conjugation of p-type electrons of the carbonyl group and nitrogen atom, allowing the electrons to smear out along the $\mathrm{C}-\mathrm{N}$ bond. In the para-disubstituted phenyl ring, the calculated $\mathrm{C}_{25}-\mathrm{H}_{44}(1.0789 \AA)$ bond length is shorter than that of the other $\mathrm{C}$-C bonds; also, $\mathrm{O}_{18} \cdots \mathrm{H}_{44}$ distance is $2.25 \AA$, which is significantly shorter than the van der Waals radius $(2.72 \AA$ ) [21] between $\mathrm{O}$ and $\mathrm{H}$ atoms, which indicates the possibility of $\mathrm{C}-\mathrm{H} \cdots \mathrm{O}$ hydrogen bonding. The elongation of the $\mathrm{C}_{20}-\mathrm{C}_{21}(1.4004 \AA)$ bond is due to the transfer of a lone pair of electrons from the amide nitrogen to the carbon atom. In the other phenyl ring, the $\mathrm{C}_{5}-\mathrm{H}_{31}$ 


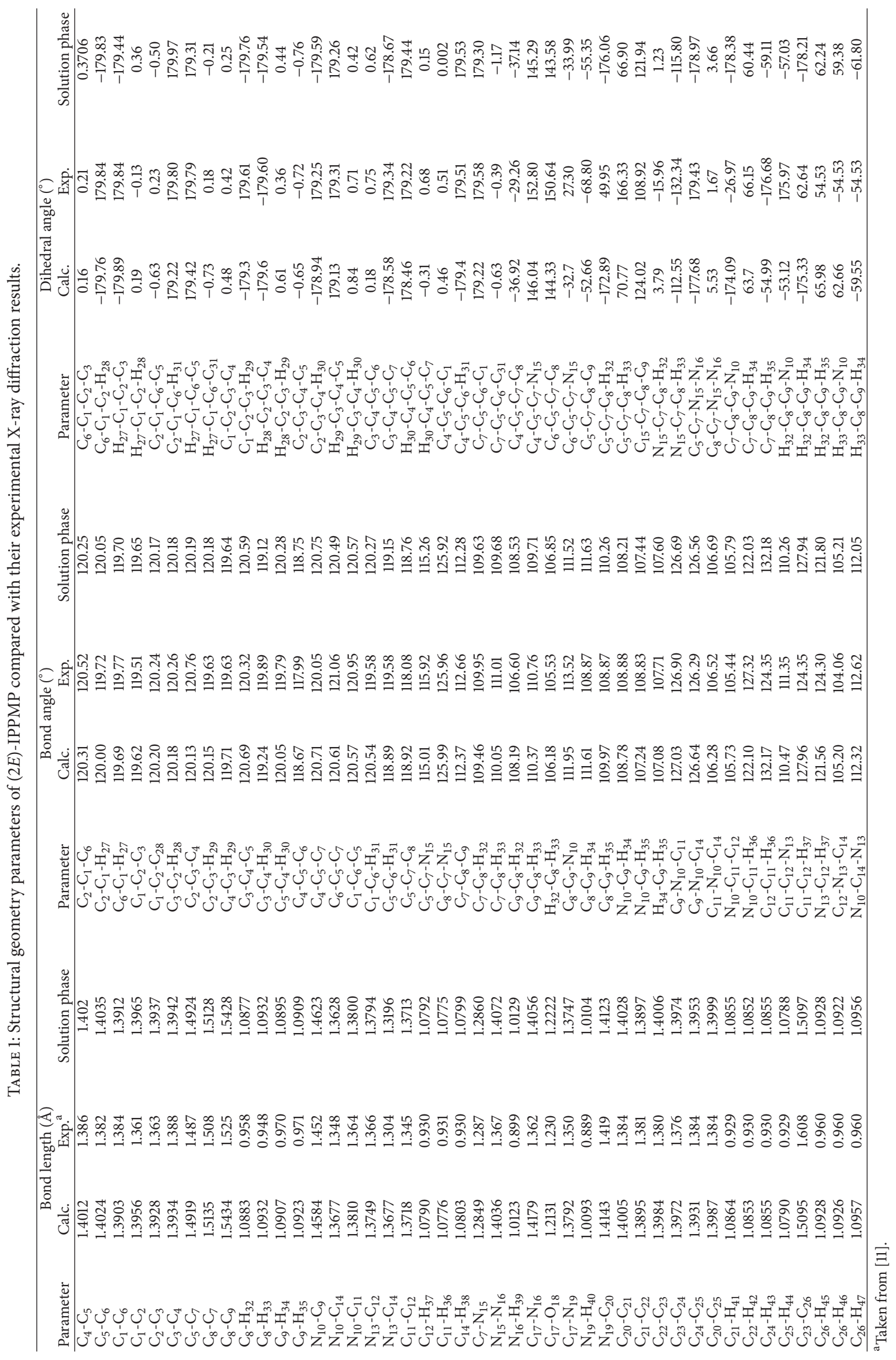


TABLE 2: Second-order perturbation theory analysis of Fock matrix in natural bond orbital (NBO) basis for (2E)-IPPMP.

\begin{tabular}{|c|c|c|c|c|c|c|}
\hline Donor $(i)$ & Occupancy (e) & Acceptor $(j)$ & Occupancy (e) & $\begin{array}{c}E(2)^{\mathrm{a}} \\
\mathrm{kcal} / \mathrm{mol}\end{array}$ & $\begin{array}{c}E(j)-E(i)^{\mathrm{b}} \\
(\mathrm{a} . \mathrm{u})\end{array}$ & $\begin{array}{c}E(i, j)^{\mathrm{c}} \\
(\text { a.u }) \\
\end{array}$ \\
\hline $\mathrm{n}_{1}\left(\mathrm{~N}_{10}\right)$ & 1.55554 & $\pi^{*}\left(\mathrm{C}_{11}-\mathrm{C}_{12}\right)$ & 1.85684 & 30.62 & 0.29 & 0.087 \\
\hline $\mathrm{n}_{1}\left(\mathrm{~N}_{10}\right)$ & 1.55554 & $\pi^{*}\left(\mathrm{~N}_{13}-\mathrm{C}_{14}\right)$ & 1.86721 & 46.48 & 0.28 & 0.103 \\
\hline $\mathrm{n}_{1}\left(\mathrm{~N}_{13}\right)$ & 1.9234 & $\sigma^{*}\left(\mathrm{C}_{11}-\mathrm{C}_{12}\right)$ & 1.98419 & 5.1 & 0.95 & 0.063 \\
\hline $\mathrm{n}_{1}\left(\mathrm{~N}_{15}\right)$ & 1.92552 & $\sigma^{*}\left(\mathrm{C}_{7}-\mathrm{C}_{8}\right)$ & 1.97792 & 11.4 & 0.79 & 0.086 \\
\hline $\mathrm{n}_{1}\left(\mathrm{~N}_{15}\right)$ & 1.92552 & $\sigma^{*}\left(\mathrm{~N}_{16}-\mathrm{H}_{39}\right)$ & 1.97686 & 2.02 & 0.77 & 0.036 \\
\hline $\mathrm{n}_{1}\left(\mathrm{~N}_{16}\right)$ & 1.79578 & $\pi^{*}\left(\mathrm{C}_{7}-\mathrm{N}_{15}\right)$ & 1.94162 & 9.06 & 0.36 & 0.052 \\
\hline $\mathrm{n}_{2}\left(\mathrm{O}_{18}\right)$ & 1.83834 & $\sigma^{*}\left(\mathrm{~N}_{16}-\mathrm{C}_{17}\right)$ & 1.98245 & 26.84 & 0.63 & 0.118 \\
\hline $\mathrm{n}_{2}\left(\mathrm{O}_{18}\right)$ & 1.83834 & $\sigma^{*}\left(\mathrm{C}_{17}-\mathrm{N}_{19}\right)$ & 1.98641 & 24.58 & 0.69 & 0.119 \\
\hline $\mathrm{n}_{2}\left(\mathrm{O}_{18}\right)$ & 1.83834 & $\sigma^{*}\left(\mathrm{C}_{25}-\mathrm{H}_{44}\right)$ & 1.97725 & 0.78 & 0.73 & 0.022 \\
\hline $\mathrm{n}_{1}\left(\mathrm{~N}_{19}\right)$ & 1.70657 & $\pi^{*}\left(\mathrm{C}_{20}-\mathrm{C}_{25}\right)$ & 1.64309 & 30.72 & 0.31 & 0.089 \\
\hline$\pi\left(\mathrm{C}_{2}-\mathrm{C}_{3}\right)$ & 1.6583 & $\pi^{*}\left(\mathrm{C}_{4}-\mathrm{C}_{5}\right)$ & 1.64969 & 20.62 & 0.28 & 0.069 \\
\hline$\pi\left(\mathrm{C}_{4}-\mathrm{C}_{5}\right)$ & 1.64969 & $\pi^{*}\left(\mathrm{C}_{1}-\mathrm{C}_{6}\right)$ & 1.66001 & 19.97 & 0.29 & 0.067 \\
\hline$\pi\left(\mathrm{C}_{11}-\mathrm{C}_{12}\right)$ & 1.85684 & $\pi^{*}\left(\mathrm{~N}_{13}-\mathrm{C}_{14}\right)$ & 1.86721 & 15.01 & 0.28 & 0.061 \\
\hline$\pi\left(\mathrm{N}_{13}-\mathrm{C}_{14}\right)$ & 1.86721 & $\pi^{*}\left(\mathrm{C}_{11}-\mathrm{C}_{12}\right)$ & 1.85684 & 21.59 & 0.33 & 0.078 \\
\hline$\pi\left(\mathrm{C}_{20}-\mathrm{C}_{25}\right)$ & 1.64309 & $\pi^{*}\left(\mathrm{C}_{21}-\mathrm{C}_{22}\right)$ & 1.70752 & 19.29 & 0.28 & 0.066 \\
\hline$\pi\left(\mathrm{C}_{20}-\mathrm{C}_{25}\right)$ & 1.64309 & $\pi^{*}\left(\mathrm{C}_{23}-\mathrm{C}_{24}\right)$ & 1.64872 & 20.41 & 0.3 & 0.069 \\
\hline$\pi\left(\mathrm{C}_{23}-\mathrm{C}_{24}\right)$ & 1.64872 & $\pi^{*}\left(\mathrm{C}_{20}-\mathrm{C}_{25}\right)$ & 1.64309 & 20.68 & 0.27 & 0.068 \\
\hline$\pi\left(\mathrm{C}_{23}-\mathrm{C}_{24}\right)$ & 1.64872 & $\pi^{*}\left(\mathrm{C}_{21}-\mathrm{C}_{22}\right)$ & 1.70752 & 22.11 & 0.27 & 0.069 \\
\hline$\pi\left(\mathrm{N}_{13}-\mathrm{C}_{14}\right)$ & 1.86721 & $\pi^{*}\left(\mathrm{C}_{11}-\mathrm{C}_{12}\right)$ & 1.85684 & 107.4 & 0.01 & 0.06 \\
\hline$\sigma\left(\mathrm{C}_{26}-\mathrm{H}_{46}\right)$ & 1.98674 & $\sigma^{*}\left(\mathrm{C}_{23}-\mathrm{C}_{24}\right)$ & 1.64872 & 0.84 & 0.54 & 0.021 \\
\hline$\sigma\left(\mathrm{C}_{26}-\mathrm{H}_{47}\right)$ & 1.97658 & $\sigma^{*}\left(\mathrm{C}_{23}-\mathrm{C}_{24}\right)$ & 1.64872 & 4.34 & 0.54 & 0.047 \\
\hline$\pi\left(\mathrm{C}_{20}-\mathrm{C}_{25}\right)$ & 1.64309 & $\pi^{*}\left(\mathrm{C}_{23}-\mathrm{C}_{24}\right)$ & 1.64872 & 254.22 & 0.01 & 0.082 \\
\hline$\pi\left(\mathrm{C}_{21}-\mathrm{C}_{22}\right)$ & 1.70752 & $\pi^{*}\left(\mathrm{C}_{23}-\mathrm{C}_{24}\right)$ & 1.64872 & 230.93 & 0.01 & 0.084 \\
\hline
\end{tabular}

${ }^{\mathrm{a}} E(2)$ means energy of hyperconjugative interactions. ${ }^{\mathrm{b}}$ Energy difference between donor and acceptor $i$ and $j \mathrm{NBO} .{ }^{\mathrm{c}} F(i, j)$ is the Fock matrix element between $i$ and $j \mathrm{NBO}$.

$(1.0825 \AA)$ bond is shorter than that of the other C-C bonds; also, $\mathrm{N}_{15} \cdots \mathrm{H}_{31}$ distance is $2.56 \AA$, which is significantly shorter than the van der Waals radius $(2.75 \AA)$ between $\mathrm{N}$ and $\mathrm{H}$ atoms, which indicates the possibility of $\mathrm{C}-\mathrm{H} \cdots \mathrm{O}$ hydrogen bonding. In addition, $\mathrm{C}_{5}-\mathrm{C}_{6}(1.4024 \AA)$ and $\mathrm{C}_{4}$ $\mathrm{C}_{5}(1.4012 \AA)$ bond distances on either side of the cyanide group are appreciably greater than the other $\mathrm{C}-\mathrm{C}$ bonds due to the resonance effect between the cyanide group and phenyl ring. In the imidazole ring, $\mathrm{C}_{14}-\mathrm{N}_{10}(1.3676 \AA)$ and $\mathrm{C}_{14}-\mathrm{N}_{13}$ $(1.3139 \AA)$ bonds are relatively shorter due to the lone pair interaction from the nitrogen atom. The deviation of bond lengths of $\mathrm{N}_{15}-\mathrm{H}_{39}(1.0123 \AA)$ and $\mathrm{N}_{19}-\mathrm{H}_{40}(1.0092 \AA)$ is due to the different environment of the nitrogen atom. Conjugation of the carbonyl group with the hydrazine moiety would favor planarity, but the van der Waals repulsion between $\mathrm{H}_{39}$ and $\mathrm{H}_{40}$ hinders the achievement of coplanarity. A small deviation was obtained within the calculated structural parameters in the gas and liquid phases, which were due to the solvent interactions over the solution phase calculations.

3.3. Natural Bond Orbital Analysis. Natural bond orbital (NBO) analysis was performed using the NBO 3.1 program [22] as implemented in the Gaussian 09 program package for the DFT method. The corresponding results are presented in Table 2. NBO analysis has proved to be an effective tool for chemical interpretation of hyperconjugative interaction and electron density transfer (EDT) from a filled lone pair to an unfilled antibonding orbital in the hydrogen bonding system [23-25]. The intramolecular C-H... O hydrogen bonding is formed due to the orbital overlap between $\mathrm{n}(\mathrm{O})$ and $\sigma^{*}(\mathrm{C}-\mathrm{H})$ which results in intramolecular charge transfer (ICT) causing stabilization of $\mathrm{H}$-bonded systems. This interaction results in increased electron density (ED) of the $\mathrm{C}-\mathrm{H}$ antibonding orbital, which strengthens the $\mathrm{C}-\mathrm{H}$ bond. $\mathrm{NBO}$ analysis confirms C-H. . O intramolecular hydrogen bonding formed by the orbital overlap between a lone pair $\mathrm{n}_{2}\left(\mathrm{O}_{18}\right)$ and $\sigma^{*}\left(\mathrm{C}_{25}-\mathrm{H}_{44}\right)$ antibonding orbital with stabilization energy of $0.78 \mathrm{kcal} / \mathrm{mol}$. The most important interaction $\left(\mathrm{n}-\pi^{*}\right)$ and $\left(\mathrm{n}-\sigma^{*}\right)$ energies of $\mathrm{n}_{1}\left(\mathrm{~N}_{10}\right) \rightarrow \pi^{*}\left(\mathrm{~N}_{13}-\mathrm{C}_{14}\right)$ and $\mathrm{n}_{2}\left(\mathrm{O}_{18}\right) \rightarrow$ $\sigma^{*}\left(\mathrm{~N}_{16}-\mathrm{C}_{17}\right)$ are 46.48 and $26.84 \mathrm{kcal} / \mathrm{mol}$, respectively. This larger $E(2)$ value shows ICT interactions of the molecule.

3.4. Vibrational Spectral Analysis. Computed vibrational wavenumbers and atomic displacements corresponding to the different normal modes are used to identify vibrational modes. The vibrational modes are assigned on the basis of 


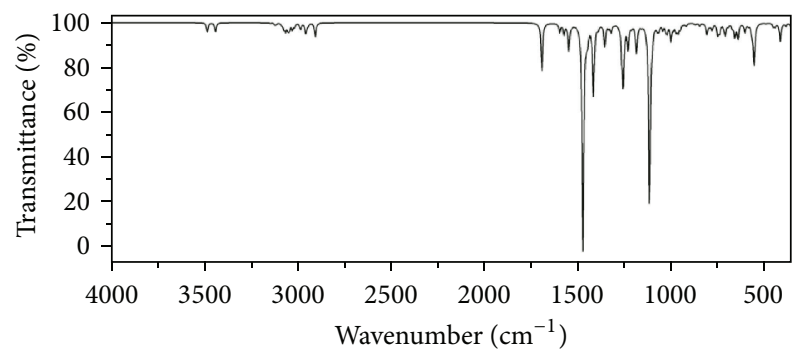

(a)

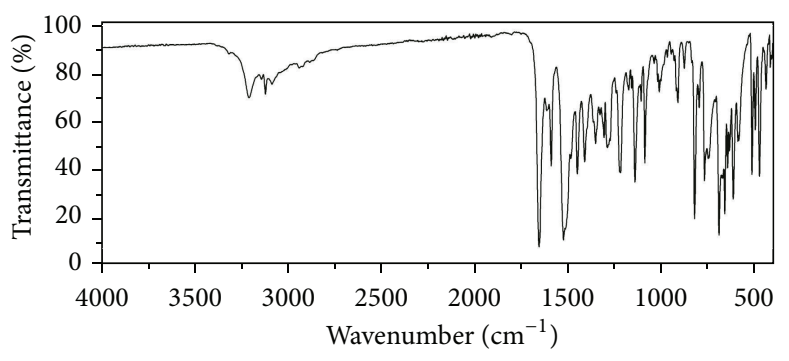

(b)

FIGURE 2: (a) Calculated (b) experiment infrared spectra of (2E)-IPPMP.

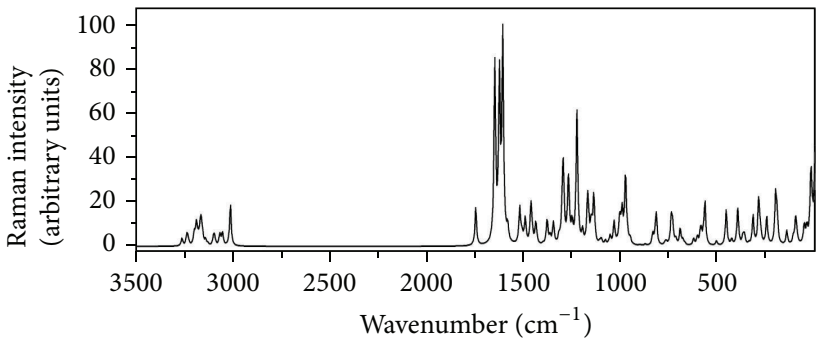

(a)

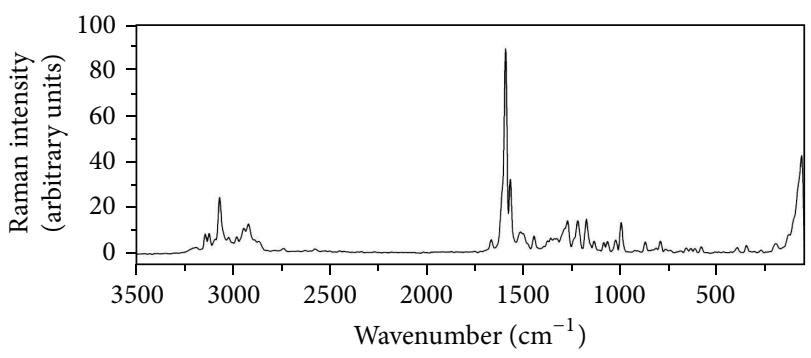

(b)

Figure 3: (a) Calculated (b) experiment Raman spectra of (2E)-IPPMP.

potential energy distribution analysis using the VEDA4 program [26]. The experimental infrared (IR) and Raman spectra are shown in Figures 2 and 3. The calculated vibrational wavenumbers, measured IR, and Raman band positions and their detailed assignments are given in Table 3.

3.4.1. Phenyl Ring Vibrations. Aromatic $\mathrm{C}-\mathrm{H}$ stretching vibrations generally absorb in the region $3080-3010 \mathrm{~cm}^{-1}$ [27]. The observed weak IR band at $3119 \mathrm{~cm}^{-1}$ and Raman band at $3121 \mathrm{~cm}^{-1}$ correspond to aromatic $\mathrm{C}-\mathrm{H}$ stretching mode. The blue shift of the $\mathrm{C}-\mathrm{H}$ stretching wavenumber is due to weak intramolecular $\mathrm{C}-\mathrm{H} \cdots \mathrm{O}$ hydrogen bonding. Aromatic $\mathrm{C}=\mathrm{C}$ stretching vibrations occur in the region $1625-1430 \mathrm{~cm}^{-1}$ [28]. A medium IR band at $1539 \mathrm{~cm}^{-1}$ and a strong Raman band at $1591 \mathrm{~cm}^{-1}$ are observed, which correspond to aromatic $\mathrm{C}=\mathrm{C}$ stretching mode. In-plane $\mathrm{C}-\mathrm{H}$ deformation vibrations appear in the region $1290-1000 \mathrm{~cm}^{-1}$ [27]. Observed IR and Raman bands at 1288 and $1275 \mathrm{~cm}^{-1}$ are assigned to inplane $\mathrm{C}$-H deformation. In-plane ring deformation vibrations appear in the region $650-615 \mathrm{~cm}^{-1}$. Observed IR and Raman bands at 615 and $640 \mathrm{~cm}^{-1}$ are assigned to in-plane ring deformation.

3.4.2. Methylene Vibrations. Asymmetric and symmetric $\mathrm{CH}_{2}$ stretching vibrations normally appear strongly at about 2926 and $2855 \mathrm{~cm}^{-1}$ [29]. The Raman band at $2941 \mathrm{~cm}^{-1}$ is assigned to $\mathrm{CH}_{2}$ symmetric stretching vibration. Methylene scissoring vibrations normally appear in the region 1465$1445 \mathrm{~cm}^{-1}$ [29]. A medium band observed in IR at $1401 \mathrm{~cm}^{-1}$ is attributed to methylene scissoring mode. The twisting, wagging vibrations appear in the region $1422-719 \mathrm{~cm}^{-1}$ [30]. The observed strong IR band at $1141 \mathrm{~cm}^{-1}$ and weak Raman band at $1177 \mathrm{~cm}^{-1}$ are assigned to $\mathrm{CH}_{2}$ twisting modes for methylene. Wagging is observed in IR at $1352 \mathrm{~cm}^{-1}$ and Raman at $1361 \mathrm{~cm}^{-1}$.

3.4.3. Methyl Vibrations. The asymmetric C-H stretching mode of $\mathrm{CH}_{3}$ generally occurs at $2982-2962 \mathrm{~cm}^{-1}$ and $\mathrm{CH}_{3}$ symmetric stretching at $2882-2862 \mathrm{~cm}^{-1}$ [29]. A weak Raman band at $2977 \mathrm{~cm}^{-1}$ is attributed to $\mathrm{CH}_{3}$ symmetric stretching. Asymmetric bending vibrations of methyl groups occur in the region $1470-1450 \mathrm{~cm}^{-1}$ [28]. The observed weak Raman band at $1447 \mathrm{~cm}^{-1}$ is assigned to methyl scissoring vibration.

3.4.4. Secondary Amide Vibrations. Carbonyl stretching vibration in a secondary amide is expected in the region 1680 $1630 \mathrm{~cm}^{-1}$ [28]. A very strong band at $1654 \mathrm{~cm}^{-1}$ is assigned to $\mathrm{C}=\mathrm{O}$ stretching. $\mathrm{N}-\mathrm{H}$ stretching vibrations generally appear in the region $3370-3170 \mathrm{~cm}^{-1}$. Observed IR and Raman bands at 3141 and $3140 \mathrm{~cm}^{-1}$ are attributed to N-H stretching. The in-plane $\mathrm{N}-\mathrm{H}$ bending vibration usually appears from 1570 to $1515 \mathrm{~cm}^{-1}$ [28]. The observed very strong IR band at $1523 \mathrm{~cm}^{-1}$ and weak Raman band at $1527 \mathrm{~cm}^{-1}$ are assigned to in-plane $\mathrm{N}-\mathrm{H}$ bending vibration.

3.4.5. Imidazole Vibrations. Imidazole $\mathrm{C}-\mathrm{H}$ stretching vibrations are expected in the region $3145-3115 \mathrm{~cm}^{-1}[31,32]$. Observed Raman bands at 3121 and $3138 \mathrm{~cm}^{-1}$ and IR bands at 3119 and $3138 \mathrm{~cm}^{-1}$ are assigned to $\mathrm{C}-\mathrm{H}$ stretching mode. 
TABLE 3: Vibrational assignment of (2E)-IPPMP based on potential energy distribution method.

\begin{tabular}{|c|c|c|c|c|}
\hline \multicolumn{2}{|c|}{ Calculated wavenumber $\left(\mathrm{cm}^{-1}\right)$} & \multicolumn{2}{|c|}{ Experimental wavenumber $\left(\mathrm{cm}^{-1}\right)$} & \multirow{2}{*}{ Assignment with PED\% } \\
\hline Unscaled & Scaled & FT-IR & FT-Raman & \\
\hline 3610 & 3497 & $3207 w$ & - & $v \mathrm{~N}-\mathrm{H}(92)$ \\
\hline 3565 & 3453 & $3141 \mathrm{vw}$ & $3140 \mathrm{vw}$ & $v \mathrm{~N}-\mathrm{H}(99)$ \\
\hline 3265 & 3163 & $3138 \mathrm{vw}$ & $3138 w$ & $v \mathrm{C}-\mathrm{H}$ imd (83) \\
\hline 3241 & 3140 & $3119 w$ & $3121 w$ & $\nu \mathrm{C}-\mathrm{H}$ ph $(99)$ \\
\hline 3202 & 3102 & & $3118 w$ & $\nu \mathrm{C}-\mathrm{H}$ ph $(86)$ \\
\hline 3182 & 3082 & $3083 \mathrm{vw}$ & - & $v \mathrm{C}-\mathrm{H}$ ph $(67)$ \\
\hline 3164 & 3066 & - & $3065 \mathrm{~m}$ & $v \mathrm{C}-\mathrm{H}$ ph $(27)$ \\
\hline 3105 & 3008 & - & $3018 w$ & $v_{\text {as }} \mathrm{C}-\mathrm{H}(55)$ \\
\hline 3073 & 2977 & - & $2977 w$ & $v_{\text {sy }} \mathrm{C}-\mathrm{H}(36)$ \\
\hline 3059 & 2964 & - & $2941 w$ & $v_{\text {sy }}$ C-H (48) \\
\hline 3019 & 2925 & - & $2917 w$ & $v_{\text {sy }} \mathrm{C}-\mathrm{H}(18)$ \\
\hline 1776 & 1720 & $1654 \mathrm{vs}$ & - & $v \mathrm{C}=\mathrm{O}(78)$ \\
\hline 1639 & 1588 & $1589 \mathrm{~m}$ & $1593 \mathrm{vs}$ & $v \mathrm{C}_{-} \mathrm{C}$ ph $(42)$ \\
\hline 1614 & 1564 & - & $1569 \mathrm{~m}$ & $v$ C_C ph (36) \\
\hline 1553 & 1504 & $1523 \mathrm{vs}$ & $1527 \mathrm{vw}$ & $\beta \mathrm{N}-\mathrm{H}(32)$ \\
\hline 1496 & 1449 & $1449 \mathrm{~m}$ & - & $\omega \mathrm{N}-\mathrm{H}(33)$ \\
\hline 1492 & 1445 & - & $1447 \mathrm{vw}$ & $\delta_{\text {sci }}$ C-H (19) \\
\hline 1468 & 1422 & $1401 \mathrm{~m}$ & - & $\delta_{\text {sci }}$ C-H (79) \\
\hline 1399 & 1355 & $1352 \mathrm{w}$ & 1361vw & $\omega \mathrm{C}-\mathrm{H}(51)$ \\
\hline 1382 & 1339 & - & $1338 \mathrm{vw}$ & $v \mathrm{C}-\mathrm{C}$ imd (20) \\
\hline 1327 & 1286 & $1288 w$ & - & $\beta \mathrm{C}-\mathrm{H}$ ph (22) \\
\hline 1307 & 1267 & - & $1275 w$ & $\beta \mathrm{C}-\mathrm{H}$ ph (12) \\
\hline 1263 & 1223 & - & $1222 w$ & $\beta \mathrm{C}-\mathrm{H}$ ph (46) \\
\hline 1258 & 1219 & $1218 \mathrm{~m}$ & - & $\beta \mathrm{C}-\mathrm{H}$ ph (56) \\
\hline 1209 & 1171 & $1174 \mathrm{vw}$ & - & $\beta \mathrm{C}-\mathrm{H}$ ph (28) \\
\hline 1177 & 1140 & $1141 \mathrm{~s}$ & $1177 \mathrm{w}$ & $t \mathrm{C}-\mathrm{H}(18)$ \\
\hline 1118 & 1084 & $1089 \mathrm{~m}$ & $1088 \mathrm{vw}$ & $\nu \mathrm{N}-\mathrm{N}(23), \beta \mathrm{C}-\mathrm{H}$ ph (12) \\
\hline 1101 & 1067 & - & $1069 \mathrm{vw}$ & $\beta \mathrm{C}-\mathrm{H}$ ph (10) \\
\hline 1075 & 1041 & $1039 \mathrm{vw}$ & - & $v \mathrm{~N}-\mathrm{N}(19)$ \\
\hline 1061 & 1028 & $1020 \mathrm{vw}$ & $1027 \mathrm{vw}$ & $\tau \mathrm{CHCH}(70)$ \\
\hline 1043 & 1011 & $1011 w$ & - & $\beta \mathrm{C}-\mathrm{H}$ imd (32) \\
\hline 1023 & 991 & - & $998 w$ & $v \mathrm{~N}-\mathrm{C}(14)$ \\
\hline 985 & 954 & $947 \mathrm{vw}$ & - & $\tau \mathrm{HCCH}(81)$ \\
\hline 947 & 918 & 931vw & - & $\tau \mathrm{CCCH}(49)$ \\
\hline 940 & 911 & $911 w$ & - & $\tau$ HCCC (47) \\
\hline 917 & 888 & $876 v w$ & $875 \mathrm{vw}$ & $\beta$ CC imd (72) \\
\hline 820 & 794 & $797 \mathrm{vw}$ & $796 \mathrm{vw}$ & $\tau \mathrm{HCCN}(55)$ \\
\hline 785 & 761 & $769 w$ & & $\nu \mathrm{C}_{-} \mathrm{C}(14)$ \\
\hline 673 & 652 & $660 \mathrm{~s}$ & $663 \mathrm{vw}$ & $\tau \mathrm{CNCN}(63)$ \\
\hline 652 & 632 & - & $640 w$ & $\beta$ CC ph (24) \\
\hline 636 & 617 & $615 \mathrm{~m}$ & - & $\tau \mathrm{CCNC}(34), \beta \mathrm{CC}$ ph $(21)$ \\
\hline 614 & 595 & $590 \mathrm{vw}$ & $586 \mathrm{vw}$ & $\tau$ CCNN $(17)$ \\
\hline 414 & 401 & - & $401 \mathrm{vw}$ & $\tau \operatorname{CCCC~}(29)$ \\
\hline 370 & 359 & - & $354 \mathrm{vw}$ & $\tau \mathrm{CCNN}(14)$ \\
\hline 199 & 193 & - & $204 \mathrm{vw}$ & $\tau \operatorname{CCCC~}(23)$ \\
\hline 71 & 69 & - & $71 \mathrm{~m}$ & $\tau \mathrm{CNCN}(14), \tau$ NNCN \\
\hline
\end{tabular}

$\nu$, stretching; $v_{\mathrm{as}}$, asymmetric; $v_{\text {sy }}$, symmetric stretching; ph, phenyl ring; imd, imidazole ring: $\delta_{\text {sci }}$, scissoring; $t$, twisting; $\omega$, wagging; $\beta$, in-plane bending; $\tau$, Torsion; vs, very strong; s, strong; m, medium; w, weak; vw, very weak. 


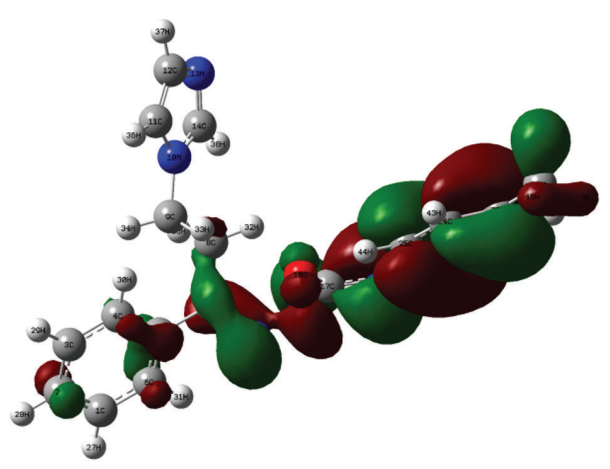

(a)

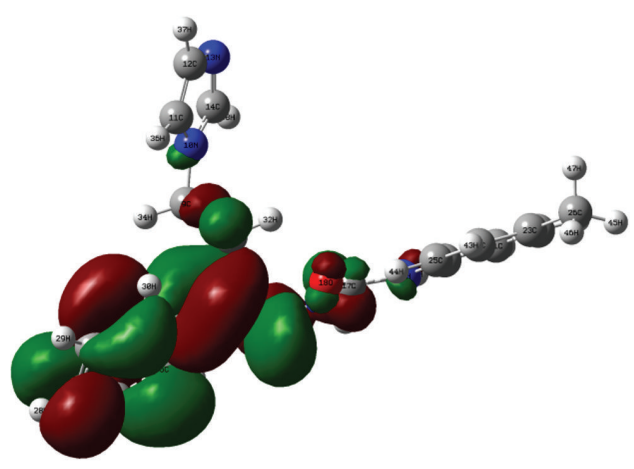

(b)

Figure 4: (a) HOMO and (b) LUMO plots of (2E)-IPPMP.

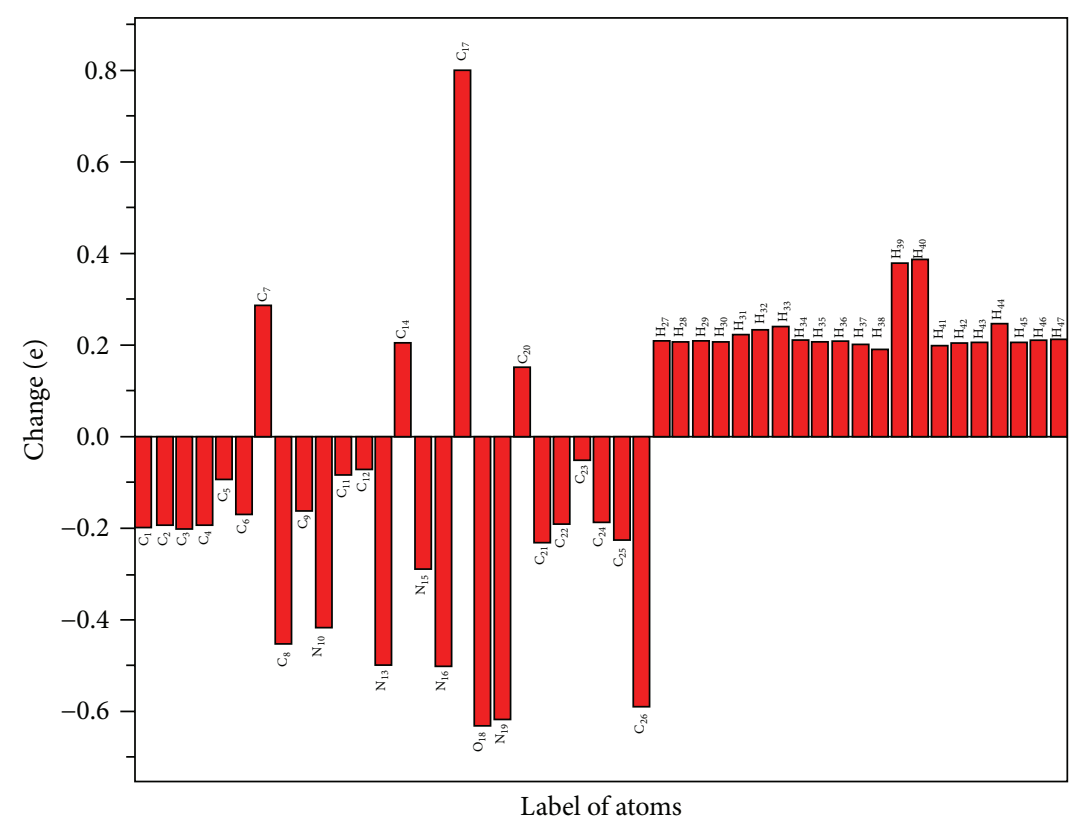

FIGURE 5: Natural charge distribution chart of the (2E)-IPPMP molecule.

The observed Raman band at $1338 \mathrm{~cm}^{-1}$ is attributed to C-C stretching mode [33].

3.4.6. Hydrazine Vibrations. In accordance with earlier reports and in agreement with the calculation, a weak band observed at $3207 \mathrm{~cm}^{-1}$ is assigned to hydrazine N-H stretching [27, 34]. Observed bands in IR and Raman at 1089 and $1088 \mathrm{~cm}^{-1}$ are assigned to $\mathrm{N}-\mathrm{N}$ stretching vibration.

3.4.7. Skeletal Mode Vibrations. C-N and C-C stretching vibrations generally occur in the region $1150-850 \mathrm{~cm}^{-1}$ [34]. The weak IR and Raman bands observed at 1011 and $998 \mathrm{~cm}^{-1}$ are attributed to $\mathrm{C}-\mathrm{C}$ stretching.

3.5. Frontier Molecular Orbital Energy Analysis. HOMO (highest occupied molecular orbital) and LUMO (lowest unoccupied molecular orbital) are important in defining the reactivity of a chemical species. The energy of HOMO indicates nucleophilicity and LUMO indicates electrophilicity [35]. HOMO is spread over the methyl phenyl, hydrazinecarboxamide fragment and LUMO is located on ph 2. This shows the charge transfer between the two rings through the hydrazinecarboxamide path. The HOMO $(-6.61 \mathrm{eV})$ and LUMO $(-1.61 \mathrm{eV})$ energies reflect the charge transfer within the molecule. The HOMO-LUMO energy gap is $4.46 \mathrm{eV}$. The frontier molecular orbital diagrams are shown in Figure 4.

3.6. Natural Population Analysis. Natural population analysis provides an effective method to calculate atomic charges and electron distribution within a molecule [36]. The net atomic charges of the (2E)-IPPMP molecule obtained by natural population analysis are plotted in Figure 5. All hydrogen atoms have a net positive charge. The atoms $\mathrm{H}_{40}(0.3852 e)$ and $\mathrm{H}_{39}(0.3788 e)$ show more positive charge than other hydrogen atoms due to their attachment with a nitrogen atom. Among the hydrogen atoms $(\sim 0.2023 e)$ of the phenyl ring, $\mathrm{H}_{44}$ 
TABLE 4: NMR chemicals shift values of ${ }^{13} \mathrm{C}$ and ${ }^{1} \mathrm{H}$.

\begin{tabular}{lccccc}
\hline & ${ }^{13} \mathrm{C}$ & & & ${ }^{1} \mathrm{H}$ & \\
Atom & $\delta_{\text {exp. }}$ & $\delta_{\text {calc. }}$ & Atom & $\delta_{\text {exp. }}$ & $\delta_{\text {calc. }}$ \\
\hline $\mathrm{C}_{1}$ & 128.3 & 128.01 & $\mathrm{H}_{27}$ & 7.39 & 7.16 \\
$\mathrm{C}_{2}$ & 128.9 & 129.41 & $\mathrm{H}_{28}$ & 7.43 & 7.19 \\
$\mathrm{C}_{3}$ & 128.3 & 127.48 & $\mathrm{H}_{29}$ & 7.39 & 7.16 \\
$\mathrm{C}_{4}$ & 128.4 & 128.13 & $\mathrm{H}_{30}$ & 7.84 & 7.50 \\
$\mathrm{C}_{5}$ & 136.8 & 138.17 & $\mathrm{H}_{31}$ & 7.84 & 7.63 \\
$\mathrm{C}_{6}$ & 128.4 & 126.71 & $\mathrm{H}_{32}$ & 3.33 & 2.61 \\
$\mathrm{C}_{7}$ & 153.6 & 168.87 & $\mathrm{H}_{33}$ & 3.33 & 2.89 \\
$\mathrm{C}_{8}$ & 28.3 & 33.31 & $\mathrm{H}_{34}$ & 4.14 & 3.77 \\
$\mathrm{C}_{9}$ & 42.1 & 44.26 & $\mathrm{H}_{35}$ & 4.14 & 3.19 \\
$\mathrm{C}_{11}$ & 119.4 & 119.36 & $\mathrm{H}_{36}$ & 6.87 & 6.87 \\
$\mathrm{C}_{12}$ & 126.4 & 128.75 & $\mathrm{H}_{37}$ & 7.29 & 6.56 \\
$\mathrm{C}_{14}$ & 137.3 & 140.01 & $\mathrm{H}_{38}$ & 7.65 & 6.82 \\
$\mathrm{C}_{17}$ & 144.9 & 150.09 & $\mathrm{H}_{39}$ & 10.24 & 6.70 \\
$\mathrm{C}_{20}$ & 131.5 & 137.03 & $\mathrm{H}_{40}$ & 8.79 & 5.70 \\
$\mathrm{C}_{21}$ & 120.0 & 115.12 & $\mathrm{H}_{41}$ & 7.13 & 6.27 \\
$\mathrm{C}_{22}$ & 128.8 & 128.43 & $\mathrm{H}_{42}$ & 7.53 & 6.80 \\
$\mathrm{C}_{23}$ & 136.3 & 132.85 & $\mathrm{H}_{43}$ & 7.53 & 6.85 \\
$\mathrm{C}_{24}$ & 128.8 & 128.53 & $\mathrm{H}_{44}$ & 7.13 & 7.90 \\
$\mathrm{C}_{25}$ & 120.0 & 114.58 & $\mathrm{H}_{45}$ & 2.28 & 1.78 \\
$\mathrm{C}_{26}$ & 20.4 & 18.25 & $\mathrm{H}_{46}$ & 2.28 & 1.80 \\
& & & $\mathrm{H}_{47}$ & 2.28 & 2.08 \\
\hline & & & & &
\end{tabular}

$(\sim 0.2452 e)$ shows the highest positive charge, being involved in $\mathrm{C}-\mathrm{H} \cdots \mathrm{O}$ intramolecular hydrogen bonding. All carbon atoms are negatively charged except $\mathrm{C}_{7}, \mathrm{C}_{14}, \mathrm{C}_{17}$, and $\mathrm{C}_{20}$ due to their attachment with electronegative nitrogen or oxygen atoms. The atom $\mathrm{C}_{17}(0.7991 e)$ shows more positive charge and $\mathrm{N}_{19}(-0.6181 e)$ shows more negative charge, indicating charge delocalization in the molecule.

3.7. NMR Analysis. The scaled and experimental NMR $\left({ }^{1} \mathrm{H}\right.$ and ${ }^{13} \mathrm{C}$ ) chemical shift values for the (2E)-IPPMP molecule are presented in Table 4. The phenyl and imidazole ring carbon signals usually appear in the region 115-150 ppm. In this molecule, imidazole ring carbon signals are obtained at $119.4,126.4$, and $137.3 \mathrm{ppm}$, which are predicted at 119.36, 128.75 , and $140.01 \mathrm{ppm}$, respectively.

Phenyl carbon signals were observed at 120.0, 128.4, 128.8, $128.9,131.5,136.3,136.8$, and $137.3 \mathrm{ppm}$, while their respective calculated ones were obtained at 115.12, 128.13, 128.53, 129.41, $137.03,132.85,138.17$, and $140.01 \mathrm{ppm}$. A carbonyl carbon signal was seen at $144.9 \mathrm{ppm}$ and its computed one was obtained at $150.09 \mathrm{ppm}$. This deviation may occur due to the presence of amide $\cdots$ amide interactions in the crystalline state. On the other hand, the computed ${ }^{1} \mathrm{H}$ chemical shift values for the title molecule showed good agreement with the experimental ones (Table 4).

3.8. Molecular Docking Analysis. The title molecule (2E)IPPMP was energy minimized based on the DFT method. Molecular docking was performed using AutoDock 4.2. A target protein (PDB ID: 1EOU) for antiepileptic agents was selected for the present docking analysis $[37,38]$. The protein
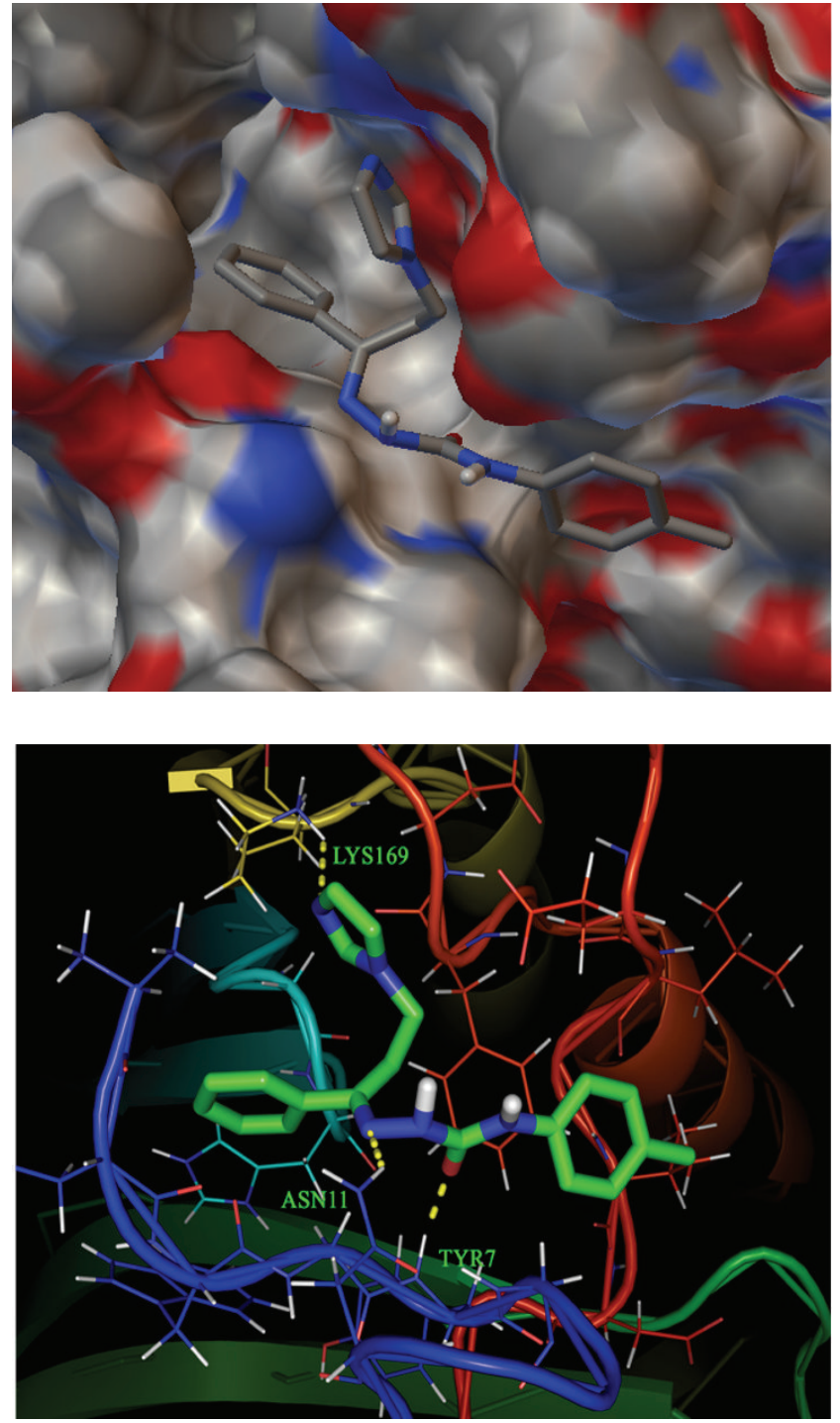

FIGURE 6: Binding pose diagrams of the (2E)-IPPMP molecule with its target protein.

data bank file of the target protein was downloaded from the Research Collaboratory for Structural Bioinformatics (RCSB) database, with a resolution of $2.1 \AA$. Protein preparation was carried out by the following steps: (i) all water molecules were removed, (ii) hydrogen atoms were added to the crystal structure, (iii) Kollman charge was added, and (iv) a previously docked inhibitor (fructose-based sugar sulfamate RWJ-37497) was removed from the protein. Rigid protein and flexible ligand dockings were carried out using the AutoDock 4.2 program package [39] with the Lamarckian genetic algorithm, applying the following protocol: trials of 100 dockings, energy evaluations of 25000000 , population size of 200, mutation rate of 0.02 , crossover rate of 0.8 , and elitism value of 1 . The docking results were evaluated by sorting the docked conformations according to their predicted binding free energy. The protein-ligand interaction complex is given in Figure 6, displaying the conformer with the best predicted binding free energy $(-7.94 \mathrm{kcal} / \mathrm{mol})$. 
The amino acids ASN11, TYR7, and LYS169 in the active sites of the target protein bind with the (2E)-IPPMP ligand by $\mathrm{N}-\mathrm{H} \cdots \mathrm{O}$ and $\mathrm{N}-\mathrm{H} \cdots \mathrm{N}$ hydrogen bonds. These preliminary results support the exhibited anticonvulsant activity of the title molecule.

\section{Conclusions}

The geometry optimization and harmonic wavenumbers of the (2E)-IPPMP molecule have been performed at ground state calculations using the DFT method. FT-IR and FTRaman measurements helped functional group identification of the title molecule. The fundamental wavenumbers are in good agreement with the theoretical results. Shifting of vibrational wavenumbers and hyperconjugative results confirmed the presence of intermolecular/intramolecular interactions in the molecule. The molecular docking results predicted the anticonvulsant activity of the (2E)-IPPMP molecule due to its ability to interact with a target protein (1EOU) for anticonvulsants. The results of the current study will support the development of new drug-like candidates in the anticonvulsant research area.

\section{Competing Interests}

The authors have declared that there are no competing interests.

\section{Acknowledgments}

The authors would like to extend their sincere appreciation to the Deanship of Scientific Research at King Saud University for its funding of this research through the Research Group Project no. RGP-196.

\section{References}

[1] O. K. Steinlein and D. Bertrand, "Nicotinic receptor channelopathies and epilepsy," Pflugers Archiv-European Journal of Physiology, vol. 460, no. 2, pp. 495-503, 2010.

[2] O. K. Steinlein, J. C. Mulley, P. Propping et al., "A missense mutation in the neuronal nicotinic acetylcholine receptor $\alpha 4$ subunit is associated with autosomal dominant nocturnal frontal lobe epilepsy," Nature Genetics, vol. 11, no. 2, pp. 201-203, 1995.

[3] M. De Groot, J. C. Reijneveld, E. Aronica, and J. J. Heimans, "Epilepsy in patients with a brain tumour: focal epilepsy requires focused treatment," Brain, vol. 135, no. 4, pp. 1002-1016, 2012.

[4] R. Gudipati, R. N. Anreddy, and S. Manda, "Synthesis, anticancer and antioxidant activities of some novel $\mathrm{N}$-(benzo[d] oxa zol-2-yl)-2-(7- or 5-substituted-2-oxoindolin-3-ylidene) hydrazinecarboxamide derivatives," Journal of Enzyme Inhibition and Medicinal Chemistry, vol. 26, no. 6, pp. 813-818, 2011.

[5] M. K. Biyala, N. Fahmi, and R. V. Singh, "Antifertility and antimicrobial activities of palladium and platinum complexes of 6-nitro-3-(indolin-2-one) hydrazine carbothioamide and 6nitro-3-(indolin-2-one)hydrazinecarboxamide," Indian Journal of Chemistry-Section A: Inorganic, Physical, Theoretical and Analytical Chemistry, vol. 45, no. 9, pp. 1999-2005, 2006.
[6] S. J. Gilani, S. A. Khan, N. Siddiqui, S. P. Verma, P. Mullick, and O. Alam, "Synthesis and in vitro antimicrobial activity of novel $N$-(6-chlorobenzo[d] thiazol-2-yl) hydrazine carboxamide derivatives of benzothiazole class," Journal of Enzyme Inhibition and Medicinal Chemistry, vol. 26, no. 3, pp. 332-340, 2011.

[7] D.-S. Guo, "Synthesis and antibacterial activities of 2-benzoyl$N$-aryl hydrazinecarboxamides," Chinese Journal of Organic Chemistry, vol. 24, no. 9, pp. 1118-1121, 2004.

[8] O. Alam, P. Mullick, S. P. Verma et al., "Synthesis, anticonvulsant and toxicity screening of newer pyrimidine semicarbazone derivatives," European Journal of Medicinal Chemistry, vol. 45, no. 6, pp. 2467-2472, 2010.

[9] M. I. Attia, M. N. Aboul-Enein, A. A. El-Azzouny, Y. A. Maklad, and H. A. Ghabbour, "Anticonvulsant potential of certain new (2E)-2-[1-Aryl-3-(1H -imidazol-1-yl)propylidene]- $N$ (aryl/H)hydrazinecarboxamides," The Scientific World Journal, vol. 2014, Article ID 357403, 9 pages, 2014.

[10] G. S. Badu, N. Rajani, P. S. Malathy, B. Srinivas, U. Kulandaivelu, and J. V. Rao, "Synthesis, characterization and evaluation of novel $N$-(1H-benzimidazol-2-yl)-2-isatinylidene-hydrazinecarboxamide derivatives as anti-inflammatory agents," Der Pharma Chemica, vol. 2, no. 3, pp. 196-204, 2010.

[11] M. I. Attia, H. A. Ghabbour, H. W. Darwish, and H.-K. Fun, "Crystal structure of (2E)-2-[3-(1H-imidazol-1-yl)-1-phenylpropylidene]- $N$-(4-methylphenyl)hydrazinecarboxamide, $\mathrm{C}_{20} \mathrm{H}_{21} \mathrm{~N}_{5} \mathrm{O}$," Zeitschrift fur Kristallographie-New Crystal Structures, vol. 229, no. 4, pp. 311-312, 2014.

[12] M. N. Aboul-Enein, A. A. El-Azzouny, M. I. Attia et al., "Design and synthesis of novel stiripentol analogues as potential anticonvulsants," European Journal of Medicinal Chemistry, vol. 47, no. 1, pp. 360-369, 2012.

[13] M. N. Aboul-Enein, A. A. E.-S. El-Azzouny, M. I. Attia, O. A. Saleh, and A. L. Kansoh, "Synthesis and anti-Candida potential of certain novel 1-[(3-substituted-3-phenyl)propyl]-1Himidazoles," Archiv der Pharmazie, vol. 344, no. 12, pp. 794-801, 2011.

[14] M. J. Frisch, G. W. Trucks, H. B. Schlegel et al., Gaussian 09, Revision A.02, Gaussian, Inc, Wallingford, Conn, USA, 2009.

[15] A. D. Becke, "Density-functional thermochemistry. III. The role of exact exchange," The Journal of Chemical Physics, vol. 98, no. 7, pp. 5648-5652, 1993.

[16] A. D. Becke, "Density-functional exchange-energy approximation with correct asymptotic behavior," Physical Review A, vol. 38, no. 6, pp. 3098-3100, 1988.

[17] C. Lee, W. Yang, and R. G. Parr, "Development of the ColleSalvetti correlation-energy formula into a functional of the electron density," Physical Review B, vol. 37, no. 2, pp. 785-789, 1988.

[18] A. P. Scott and L. Radom, "Harmonic vibrational frequencies: an evaluation of Hartree-Fock, Møller-Plesset, quadratic configuration interaction, density functional theory, and semiempirical scale factors," Journal of Physical Chemistry, vol. 100, no. 41, pp. 16502-16513, 1996.

[19] J. P. Merrick, D. Moran, and L. Radom, "An evaluation of harmonic vibrational frequency scale factors," Journal of Physical Chemistry A, vol. 111, no. 45, pp. 11683-11700, 2007.

[20] T. Engel, G. Drobny, and P. J. Reid, Physical Chemistry for the Life Sciences, Pearson Prentice Hall, New York, NY, USA, 2008.

[21] R. A. Klein, "Modified van der Waals atomic radii for hydrogen bonding based on electron density topology," Chemical Physics Letters, vol. 425, no. 1-3, pp. 128-133, 2006. 
[22] E. D. Glendening, A. E. Reed, J. E. Carpenter, and F. Weinhold, "NBO 3.1," in Theoretical Chemistry Institute and Department of Chemistry, University of Wisconsin, Madison, Wis, USA, 1998.

[23] A. E. Reed, L. A. Curtiss, and F. Weinhold, "Intermolecular interactions from a natural bond orbital, donor-acceptor viewpoint," Chemical Reviews, vol. 88, no. 6, pp. 899-926, 1988.

[24] J. P. Foster and F. Weinhold, "Natural hybrid orbitals," Journal of the American Chemical Society, vol. 102, no. 24, pp. 7211-7218, 1980.

[25] F. Weinhold and C. R. Landis, Valency and Bonding: A Natural Bond Orbital Donor-Acceptor Perspective, Cambridge University Press, New York, NY, USA, 2005.

[26] M. H. Jamroz, "Vibrational energy distribution analysis VEDA 4," Warsaw, 2004, http://smmg.pl/software/sowtware-veda .html.

[27] G. Socrates, Infrared Characteristic Group Frequencies, John Wiley \& Sons, New York, NY, USA, 1980.

[28] B. C. Smith, Infrared Spectral Interpretation: A Systematic Approach, CRC Press, New York, NY, USA, 1999.

[29] N. B. Colthup, L. H. Daly, and S. E. Wiberley, Introduction to Infrared and Raman Spectroscopy, Academic Press, New York, NY, USA, 1990.

[30] G. Varsanyi, Vibrational Spectra of Benzene Derivatives, Academic Press, New York, NY, USA, 1969.

[31] A. E. Ledesma, S. A. Brandán, J. Zinczuk, O. E. Piro, J. J. L. González, and A. B. Altabef, "Structural and vibrational study of 2-(2'-furyl)-1H-imidazole," Journal of Physical Organic Chemistry, vol. 21, no. 12, pp. 1086-1097, 2008.

[32] M. Govindarajan, A. S. Abdelhameed, A. Al-Saadi, and M. Attia, "Experimental and theoretical studies of the vibrational and electronic properties of (2E)-2-[3-(1H-imidazol-1-yl)-1-phenylpropylidene]- $N$-phenylhydrazinecarboxamide: an anticonvulsant agent," Applied Sciences, vol. 5, no. 4, pp. 955-972, 2015.

[33] D. N. Sathyanarayana and D. Nicholls, "Vibrational spectra of transition metal complexes of hydrazine normal coordinate analyses of hydrazine and hydrazine- $\mathrm{d}_{4}$," Spectrochimica Acta Part A: Molecular Spectroscopy, vol. 34, no. 3, pp. 263-267, 1978.

[34] L. J. Bellamy, The Infrared Spectra of Complex Molecules, Chapman \& Hall, London, UK, 1975.

[35] I. Fleming, Molecular Orbitals and Organic Chemical Reactions, John Wiley \& Sons, Chichester, UK, 2010.

[36] A. E. Reed, R. B. Weinstock, and F. Weinhold, "Natural population analysis," The Journal of Chemical Physics, vol. 83, no. 2, pp. 735-746, 1985.

[37] R. Recacha, M. J. Costanzo, B. E. Maryanoff, and D. Chattopadhyay, "Crystal structure of human carbonic anhydrase II complexed with an anti-convulsant sugar sulphamate," Biochemical Journal, vol. 361, no. 3, pp. 437-441, 2002.

[38] H. M. Berman, J. Westbrook, Z. Feng et al., "The protein data bank," Nucleic Acids Research, vol. 28, no. 1, pp. 235-242, 2000.

[39] G. M. Morris, H. Ruth, W. Lindstrom et al., "Software news and updates AutoDock4 and AutoDockTools4: automated docking with selective receptor flexibility," Journal of Computational Chemistry, vol. 30, no. 16, pp. 2785-2791, 2009. 

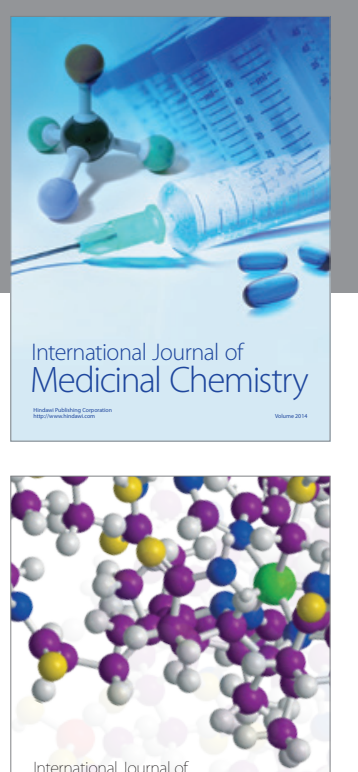

Carbohydrate Chemistry

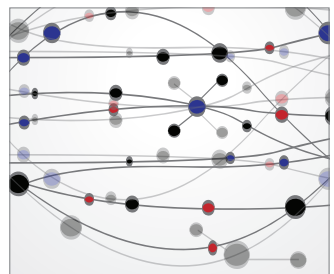

The Scientific World Journal
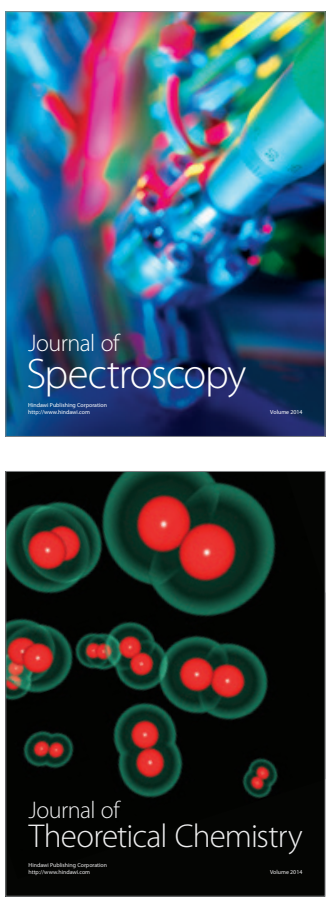
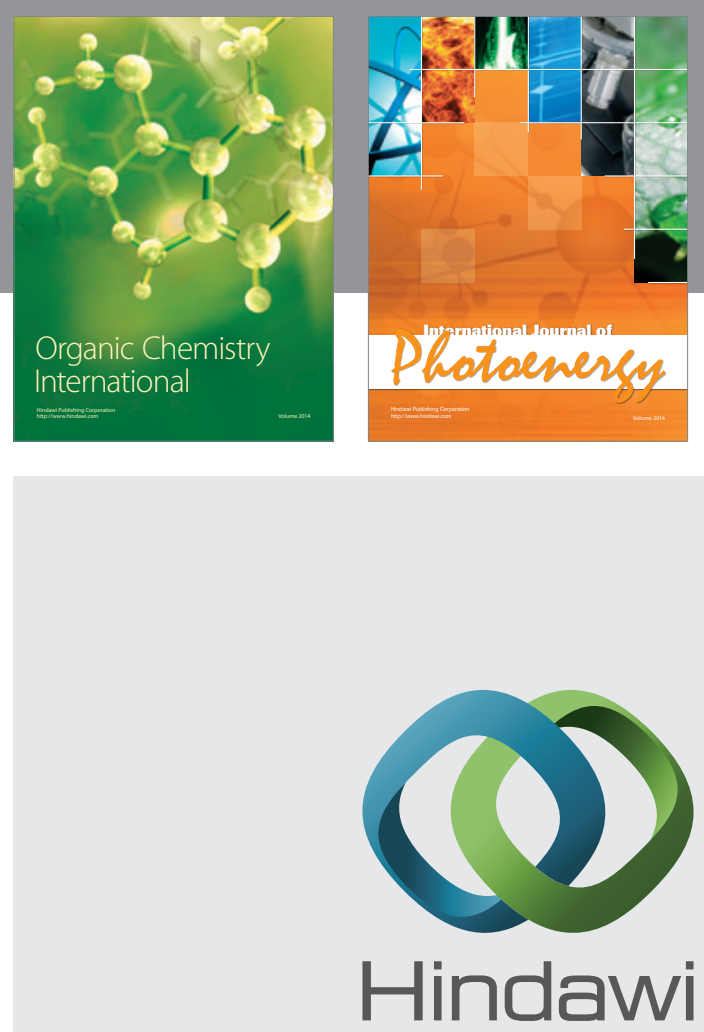

Submit your manuscripts at

http://www.hindawi.com

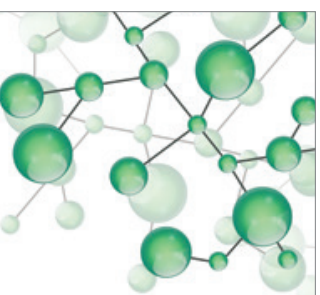

International Journal of

Inorganic Chemistry

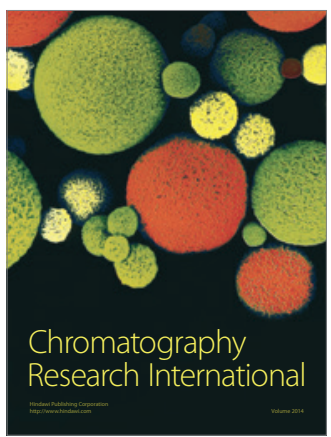

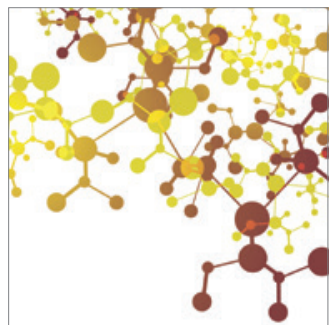

Applied Chemistry
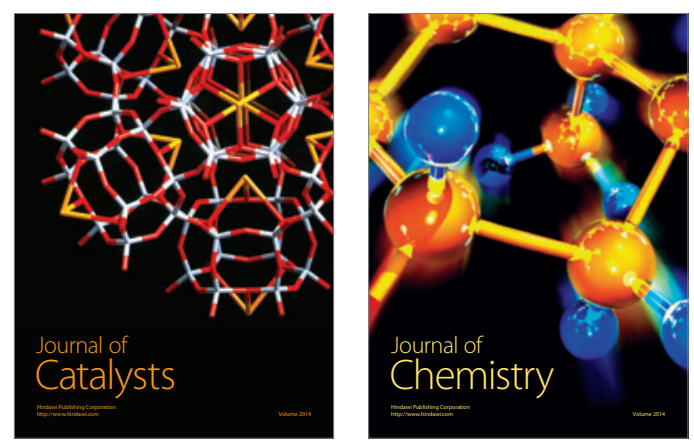
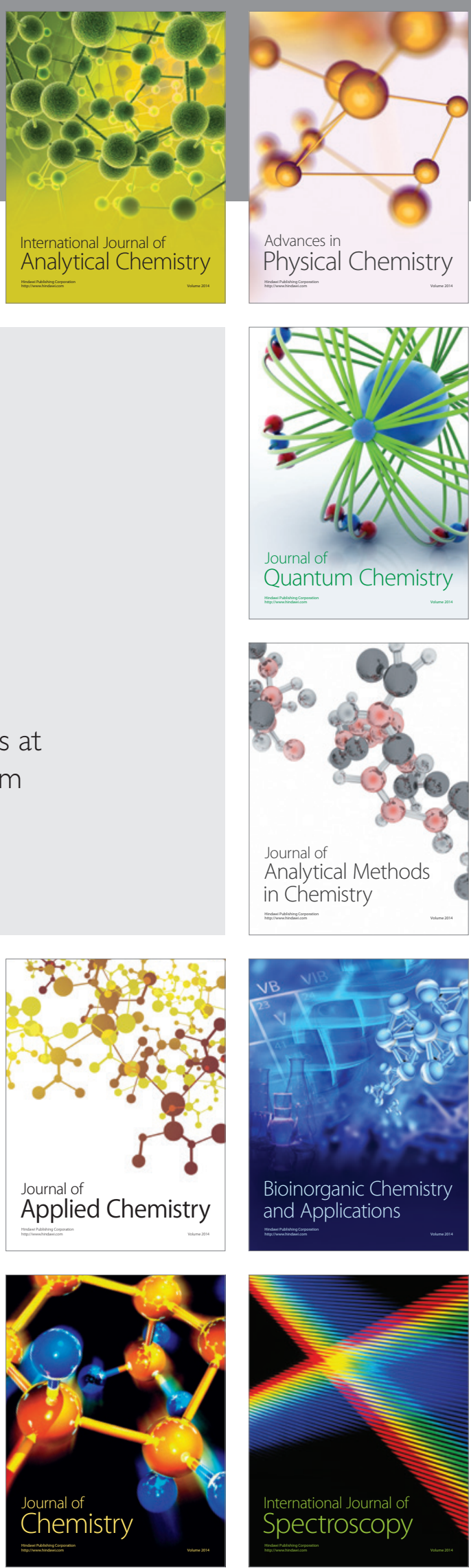